\title{
Metastatic Heterogeneity of Breast Cancer: Companion and Theranostic Approach in Nuclear Medicine
}

\author{
Christopher Montemagno $1,2, *$ and Gilles Pagès ${ }^{1,2}$ \\ 1 Département de Biologie Médicale, Centre Scientifique de Monaco, 98000 Monaco, Monaco; gpages@unice.fr \\ 2 Institute for Research on Cancer and Aging of Nice, Centre Antoine Lacassagne, CNRS UMR 7284 and \\ INSERM U1081, University Côte d'Azur, 06200 Nice, France \\ * Correspondence: montemagno.chris@gmail.com; Tel.: +377-97-77-44-10
}

Received: 21 February 2020; Accepted: 5 March 2020; Published: 29 March 2020

\begin{abstract}
Breast cancer is the most common malignancy in women throughout the world. Metastatic dissemination to vital organs is the leading cause of breast cancer-related deaths. The treatment of metastases is mainly based on the primary tumor characteristics. However, breast cancer metastases exhibit high heterogeneity leading to different prognosis and therapeutic responses. Getting access to phenotype of metastases would allow better management of patients. The advent of theranostics in nuclear medicine has opened new opportunities for the diagnosis and treatment of cancer patients. The aim of this review is to provide an overview of current knowledge and future directions in nuclear medicine for therapeutic management of metastatic breast cancer patients.
\end{abstract}

Keywords: breast cancer; metastasis; nuclear medicine; theranostics

\section{Introduction}

Breast cancer is the most common female malignancy, accounting for more than $30 \%$ of all malignant tumors in women [1]. In 2018, 2 million women were diagnosed with breast cancer [2]. Breast cancer is a complex and highly heterogeneous disease consisting of various subtypes. It is classified into human epidermal growth receptor 2 (HER-2), luminal A, luminal B and basal-like, based on histological and molecular features [3,4]. The prognosis of breast cancer patients is highly dependent of the breast cancer genotype; as patients with HER2 or basal-like cancers have worse prognoses compared to patients with luminal A or luminal B breast cancers [5]. Breast cancer prognosis is also highly dependent of the disease stage at the time of diagnosis. The five-year relative survival of early-stage breast cancer is $99 \%$, whereas the prognosis of patients with metastatic breast cancer is unfavorable with a five-year survival rate of $25 \%$ [6]. Moreover, among women initially diagnosed without metastasis, $20 \%$ to $30 \%$ will develop a metastatic disease during the next five years [7]. Metastatic breast cancers are treated by chemotherapy or targeted therapy according to primary tumor features. However, $20 \%$ to $45 \%$ of metastases exhibit different phenotypes as compared to the primary tumor [8]. Getting access to metastases phenotype would define a more accurate treatment, depending on the molecular characteristics of these lesions. Metastases are rarely accessible to biopsy. Hence, molecular imaging is of great interest. Nuclear medicine is the only molecular imaging technique available in clinical practices. In addition to accurate phenotype acquisitions, nuclear medicine allows promising therapeutic opportunities to treat a large panel of cancers including breast [9]. 


\section{Metastatic Dissemination of Breast Cancer}

\subsection{Generalities}

Metastasis is the general term used to describe the spread of cancer cells from the primary tumor to distant organs. The vast majority of cancer-related deaths arise from the metastatic spread which is responsible for $90 \%$ of cancer-related deaths [10]. The process of metastatic dissemination remains poorly understood. When the diagnosis of breast cancer is established, $5 \%$ of patients already present a metastatic disease. Despite therapeutic advances, $20 \%$ to $30 \%$ of patients will relapse towards a metastatic disease $[7,11]$. The ability of tumor cells to disseminate, which is closely linked to overall survival, is dependent on the tumor subtype. Patients with basal-like and HER2-positive tumors have the shortest metastasis-free survival and overall survival in comparison to patients with luminal A and luminal B subtypes [3,5,12].

\subsection{Metastatic Dissemination Pattern of Breast Cancer}

Breast cancers preferentially spread to the following organs: liver, lung, bone and brain. Breast cancer subtypes predict the preference to sites of distant metastasis [13,14]. Luminal A and B tumors preferentially colonize bone tissue with a lower rate of brain metastasis. HER-2-positive- and basal-like tumors exhibit higher rate of metastasis to the brain, the liver, bones and lungs [15,16]. The risk of developing brain metastases for the basal-like and HER2-positive subtypes is four times greater than for the luminal A/B subtypes [17]. Moreover, basal-like and HER-2-positive tumors are associated with early relapse $[18,19]$.

\subsection{The Metastatic Dissemination as an Early Event of Tumor Progression}

While it is widely believed that distant metastasis is a late event in tumor progression, several studies have suggested an earlier occurrence of metastatic spread. The first highlight of this phenomenon comes from the analysis of scattered cells isolated from the bone marrow of patients with non-metastatic breast cancer; the presence of isolated tumor cells in the marrow increases the risk of relapse [20-22]. Accumulating evidences have shown that dissemination of tumor cells in mouse models of breast cancers as well as in the human disease can occur in preinvasive stages of tumor progression [23]. Similar findings have recently been found in preclinical models of pancreatic cancer and melanoma [24,25]. The results acquired from patients with precancerous breast lesions or carcinomas in situ are in agreement with these findings [23,26,27].

\subsection{Metastatic Dormancy}

Most tumor cells that have carried out extravasation are unable to proliferate in the new environment and remain as micro-metastases. Micro-metastases can remain dormant for months or even years in secondary tissue. These micro-metastases constitute a residual disease characterized by the persistence of tumor cells in the body, which cannot be detected by conventional diagnostic techniques [28,29]. These cells do not exhibit histological and molecular features of transformed cells and are in a state of dormancy. The ability to isolate dormant cells is a difficult task. Hence, the mechanisms leading to metastatic dormancy remain poorly understood. The transition to clinically identifiable macro-metastases seems to coincide with the expansion of rare clones with specific genetic profiles [20]. Three molecular mechanisms characterize tumor dormancy: cell quiescence, angiogenic and immunological dormancy [30]. These dormant cells exhibit limited proliferation, an absence of Ki-67 labeling and apoptotic markers, linked to a reduced activity of PI3K-Akt pathway [31-33]. Moreover, dormant micro-metastases can also acquire a specific antigenic profile allowing them to escape the immune surveillance [34]. The regulatory mechanisms of dormancy remain to be investigated.

The early metastatic dissemination of breast cancer and the ability of tumor cells to remain quiescent should be considered as keys elements of metastatic relapse. A better understanding of metastatic processes will improve therapeutic strategies towards metastatic cancer. 


\section{Heterogeneity of Breast Cancer Metastases}

The therapeutic strategy for metastatic breast cancer relies on several parameters. It depends on the histological characteristics of the primary tumor, previous treatments and their tolerance, the site of metastatic lesions, the time to relapse and on predictive factors of treatment response (such as hormone-receptor expression or HER2 status) [35,36]. The molecular characterization of tumors is a key element in therapeutic management, but several studies have shown a lack of stability of the hormonal receptors and HER2 between the primary tumor and the metastases [8,37-39]. This observation underlines the need to reconsider the molecular status of secondary lesions to improve the treatment. Indeed, the loss of a predictive factor (HER2, ER, PR) can lead to the prescription of an unnecessary and potentially toxic treatment. Conversely, gaining a biomarker could offer interesting therapeutic opportunities for patients who did not initially receive a treatment directed against this target.

In 2012, Lindström et al. demonstrated the instability in the clinically used markers. One third of patients experienced altered expression of hormone receptor, and 15\% of HER2 expression during tumor progression [8]. Several authors further confirmed the discrepancy between the phenotype of the primary tumor and metastasis [40-42]; $15 \%$ to $40 \%$ of patients present a discrepancy in ER expression in the primary tumor and the metastases $[8,43]$. An equivalent mismatch stands for HER2 expression in up to $40 \%$ of patients $[43,44]$. The discrepancies in expression of progesterone and estrogen receptors and HER2 between tumor and metastases are observed in $33 \%, 20 \%$ and $8 \%$ of patients respectively [37].

The mechanisms leading to differential expression of these receptors have not been elucidated. Intra-tumor heterogeneity, molecular changes during the biological evolution of the tumor, the microenvironment or the selection pressure induced by therapies are probably involved as described for HER2 and hormone-receptor positive tumors following chemotherapy [45-51].

The heterogeneity between primary breast tumor and liver metastasis has recently led to a change in the therapeutic decisions, resulting as in an improvement of patients survival [52].

Currently, the molecular profile of the primary tumor and of metastases does not impact the patient's therapeutic management. It is essential to reassess this therapeutic strategy and to discover new therapeutic targets for the management of metastatic breast cancers.

The assessment of the metastatic phenotype is critical for an optimal management of metastatic breast cancer patients. In this context, nuclear imaging allows non-invasive investigations of metastases that are not accessible to a biopsy.

\section{Nuclear Medicine: Companion Marker and Theranostic Approach}

\subsection{Companion Approach}

It is a diagnostic test selecting patients eligible for a specific treatment among those diagnosed for a specific disease according to their status for a predictive marker identified by the test (Figure 1) [53]. Currently, the prescription of targeted therapies is guided by the molecular characteristics of each patient's tumor. For example, amplification of HER2 is systematically sought in patients with breast cancer, who may benefit from trastuzumab/Herceptin. In addition to the selection of patients eligible for targeted therapies, companion markers track the efficacy of these therapies.

In the context of metastasis heterogeneity, nuclear imaging and the companion approach allows phenotyping of secondary lesions, in a non-invasive and very sensitive manner. Thus, developing companion tracers select patients who benefit from therapies targeting HER2 or hormone receptors, or other treatments directed against promising targets currently in development. Metastatic heterogeneity has been tested by imaging agents targeting HER2 [54,55]. A discrepancy between the primary tumor and the metastases was demonstrated in a non-invasive manner. Ulaner et al., have imaged primary HER2-negative tumors and HER2-positive secondary lesions with ${ }^{89} \mathrm{Zr}$-trastuzumab. Hence, anti-HER2 led to significant tumor regression in these patients [55]. 
More than 150,000 patients live with metastatic breast cancer in the United States [56]. If 80\% of primary tumors are HER2 negative, and if a discrepancy is found in $8 \%$ of cases, 9600 patients do not benefit from HER2-directed therapy. Thus, HER2-directed agents could be a part of the therapeutic arsenal in a non-negligible number of patients.

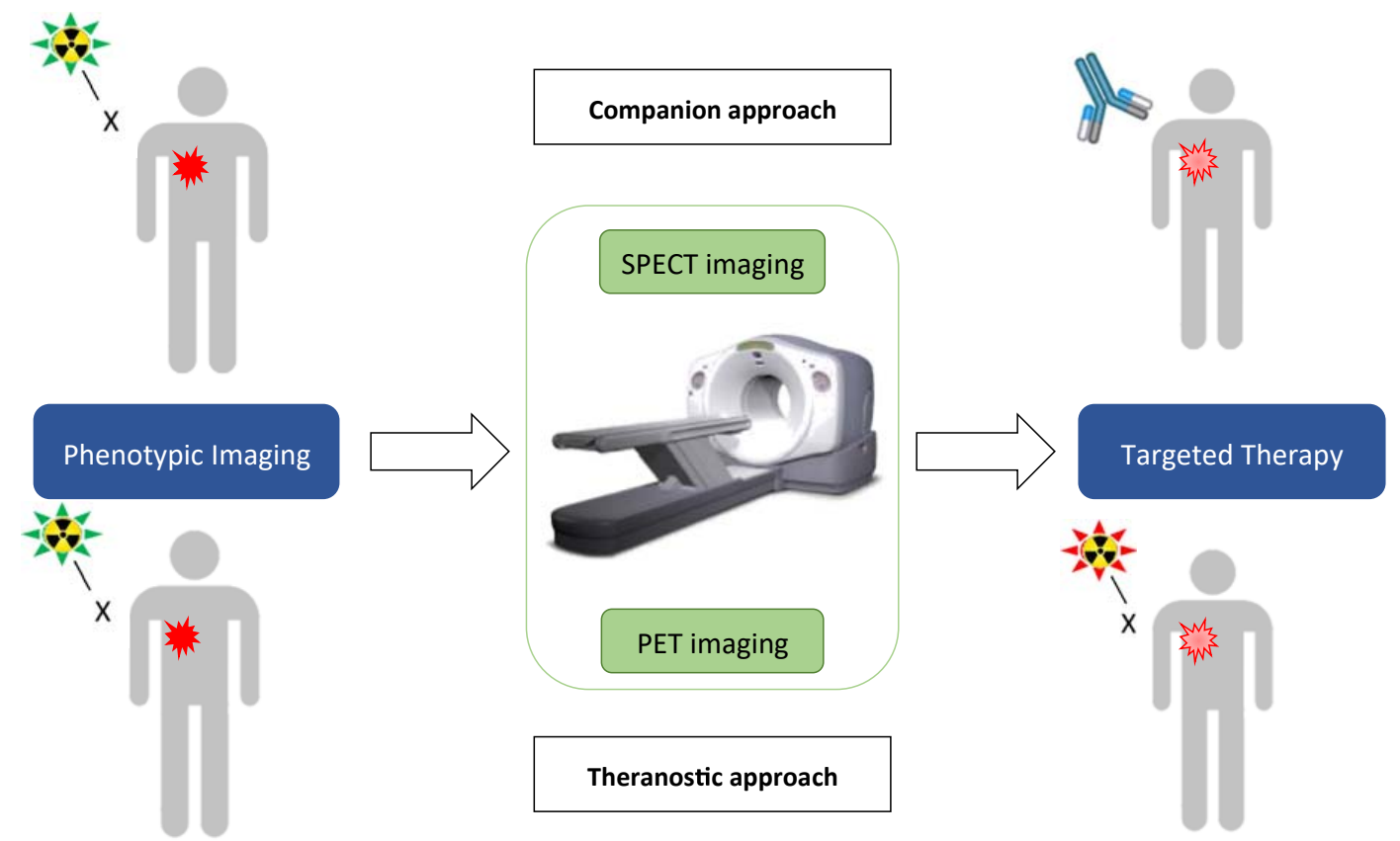

Figure 1. Companion and theranostic approaches in nuclear medicine. Phenotypic imaging (left) achieved using a PET- or SPECT-dedicated radiolabel compound can be followed by a non-radioactive therapy (right, top) or a radioactive therapy (right, bottom).

\subsection{Therapies and the Era of Theranostics}

Nuclear medicine images a target but also offers interesting therapeutic perspectives. Internal vectorized radiotherapy (IVR) is an intravenous radiotherapy using radiopharmaceuticals with a tumor tropism. It consists of specifically irradiating tumor targets using these molecules labeled by radionuclides $\beta$-emitting, $\alpha$ radiation or even Auger electrons, injected intravenously. The efficacy and toxicity of IVR depend on several parameters, including the nature of the vector, the target and the radioelement used. The radio-induced lesions by these radioelements target proteins, carbohydrates and lipids and nucleic acids (RNA and DNA). Several types of DNA damages can occur: single or double-strand breaks, DNA-DNA or DNA-protein bonds [57-59]. Radiation can also induce tumor apoptosis by activating cell death receptors [60]. The $\beta$-emitters are particularly used for targeted radiotherapy [61]. Their use in IVR therefore makes it possible to envisage the destruction of cells adjacent to the targeted cells. This "cross fire" mechanism and bystander effect can increase the effectiveness of the treatment [62]. The use of an alpha emitter in preclinical and clinical trials led to remarkable therapeutic efficacy in metastatic prostate cancer patients [63-65].

One promising and growing approach to treat cancer in nuclear medicine is theranostics, a combination of the diagnostic potential of nuclear imaging and the radiation therapy (Figure 1) [9]. Theranostics consists of using imaging to map cancer cells and then treat them in a targeted manner. The detection of potential targets predicts the relevance of a particular treatment. A typical example in theranostics is the use of $\beta^{+}$emitter 68 -Gallium $68\left({ }^{68} \mathrm{Ga}\right)$ tracers for diagnosis, followed by targeted therapy by labeling a similar or the same compound with $\beta^{-}$radionuclides, such as 177-Lutetium $\left({ }^{177} \mathrm{Lu}\right)$ or $90-Y$ ttrium $\left({ }^{90} \mathrm{Y}\right)$. These three radioelements with similar chemical conformations can be complexed to the same group for the radio-labeling of the molecule of interest [66-68]. The great advances in the field of theranostics has led to remarkable progress in the management of 
patients with prostate cancer with the use of ${ }^{68} \mathrm{Ga}$-PSMA-617/ ${ }^{177} \mathrm{Lu}$-PSMA-617, or with neuroendocrine tumors with the use of ${ }^{68} \mathrm{Ga} /{ }^{177} \mathrm{Lu}$-DOTA-TATE, while showing limited side effects [69-71]. Current clinical research shows a plethora of evidence towards the higher efficacy of alpha emitters [72]. Alpha emitter-labeled compounds have notably demonstrated remarkable therapeutic efficacy in metastatic prostate cancer [63].

This concept of theranostic medicine is perfectly suitable for management of metastatic breast cancer considering the tumor heterogeneity. By monitoring therapy according to the phenotype of these lesions, theranostic medicine can lead to more effective care while reducing unnecessary treatments.

\section{Validated and Future Imaging Agents for Metastatic Breast Cancer}

The assessment of differences between the primary tumor and the metastatic lesion, but also with different metastases in the same or different organs, requires several nuclear imaging tools with the aim of adapting treatment according to the expression of specific markers.

\subsection{HER-2 Targeting Imaging Agents}

Several clinical studies have been conducted with trastuzumab, labeled with ${ }^{64} \mathrm{Cu}$ or ${ }^{89} \mathrm{Zr}$, in patients with HER2-positive metastatic breast cancer [73,74]. A nanobody targeting HER2 has been labeled with ${ }^{99 \mathrm{~m}} \mathrm{Tc}$ and ${ }^{68} \mathrm{Ga}$ for SPECT and PET phenotypic imaging and with ${ }^{177} \mathrm{Lu}$ for radiotherapy. Its theranostic potential has been extensively validated pre-clinically in mouse models of HER2-expressing breast tumors [75-77]. Its clinical transfer is in progress. Phase I in patients with HER2-positive breast cancer demonstrated the safety of the ${ }^{68} \mathrm{Ga}$ labeled agent and its ability to target HER2-expressing breast tumors as early as $1 \mathrm{~h}$ after injection [78]. A phase II trial is underway in patients with HER2-positive metastatic breast cancer to evaluate the binding of this tracer in brain metastases (NCT03331601). HER2-positive lesions have been detected with the use of small molecules (affibody, ${ }^{68}$ Ga-ABY-025) [54].

\subsection{Estrogen-Receptor Targeting Imaging Agents}

${ }^{18}$ F-fluoro-estradiol or FES is a radiopharmaceutical agent targeting the estradiol receptor developed for PET imaging. The performance of FES-PET has been evaluated in several single-center studies between 1988 and $2011[79,80]$. The sensitivity of FES for bone and lung lesions is greater than 92\% [81]. The performance of PET-FES has also been evaluated to predict the response to hormonal treatment in metastatic breast cancer; a predictive value of $79 \%$ and a negative predictive value of $88 \%$ were demonstrated [82]. The diagnostic accuracy and safety of ${ }^{18}$ F-FES was recently assessed successfully in metastatic breast cancer patients [83]. The staging assessment of patients with metastatic breast cancer should include ${ }^{18} \mathrm{~F}$-FES-PET-CT, which is now available in clinical practice.

\subsection{Other Imaging Agents Currently in Development}

The discovery of the mechanisms and of the molecular actors in tumor progression has opened new opportunities for the management of several aggressive cancers, including metastatic breast cancer. Several targets have emerged and imaging agents targeting them are currently in preclinical or clinical development. Besides imaging agents directed against HER2 and estrogen receptors, some companion markers as well as theranostic agents could be promising for management of metastatic breast cancers (Table 1). 
Table 1. Targets and radioligands for phenotypic imaging of metastatic breast cancers.

\begin{tabular}{|c|c|c|c|c|}
\hline Molecular Target & $\begin{array}{c}\text { Expression in } \\
\text { Breast Cancer (\%) }\end{array}$ & Theranostic Molecule & Clinical Trial & References \\
\hline PARP & $45 \%$ & ${ }^{18} \mathrm{~F}$-fluorthanatrace & Yes & [84] \\
\hline Gastrin-Releasing & \multirow{2}{*}{$75.8 \%$} & ${ }^{68} \mathrm{Ga}-\mathrm{NeoBOMB1}$ & Yes & \multirow{2}{*}{ [68] } \\
\hline Peptide Receptor & & ${ }^{177} \mathrm{Lu}-\mathrm{NeoBOMB1}$ & Yes & \\
\hline \multirow{2}{*}{ PSMA } & \multirow{2}{*}{$60 \%$} & ${ }^{68}$ Ga-PSMA-617 & Yes & \multirow{2}{*}[71,85,86]{} \\
\hline & & ${ }^{177} \mathrm{Lu}-\mathrm{PSMA}-617$ & Yes & \\
\hline \multirow{4}{*}{ PD-1/PD-L1 } & \multirow{4}{*}{$29 \%$ to $50 \%$} & ${ }^{89} \mathrm{Zr}$-Pembrolizumab & Yes (Phase II) & \multirow{4}{*}{ [87] } \\
\hline & & ${ }^{89} \mathrm{Zr}$-Atezolizumab & Yes (Phase I) & \\
\hline & & ${ }^{18} \mathrm{~F}$ or ${ }^{89} \mathrm{Zr}$-Adnectin & Yes (Feasibility) & \\
\hline & & ${ }^{99 \mathrm{~m}} \mathrm{Tc}-\mathrm{Nb}$ & Yes (Phase I) & \\
\hline CXCR-4 & $56 \%$ & ${ }^{68}$ Ga-Pentixafor & Yes & [88] \\
\hline \multirow{3}{*}{ Mesothelin } & \multirow{3}{*}{$30 \%$} & ${ }^{89} \mathrm{Zr}-\mathrm{mAb}$ (MM0T0530A) & Phase I & \multirow{3}{*}{ [89-91] } \\
\hline & & ${ }^{111}$ In-Amatuximab & Phase I & \\
\hline & & ${ }^{99 m}$ Tc-A1 & No & \\
\hline
\end{tabular}

Two promising theranostic couples represent relevant candidates for the therapeutic management of breast cancer patients: the gastrin release peptide receptor GRPR-targeting and PSMA-targeting agents. The expression of the GRPR has been reported in several cancers, including $72 \%$ to $96 \%$ of breast cancers [92,93]. Several imaging agents targeting this protein have recently been evaluated. The most promising NeoBOMB1, has been labeled with ${ }^{68} \mathrm{Ga}$ and ${ }^{177} \mathrm{Lu}$ and successfully evaluated in mouse models of prostate cancer [68]. A multicenter phase I study is ongoing with ${ }^{68} \mathrm{Ga}-\mathrm{NeoBOMB} 1$ in patients with gastrointestinal stromal tumors resistant to conventional therapies (NCT02931929). Theranostic agents targeting PSMA and, notably, ${ }^{68} \mathrm{Ga}$-PSMA-617 represent new tools of the therapeutic arsenal against metastatic breast cancer, since PSMA-based PET/CT imaging, which is now available in clinical practice is the procedure of choice in case of recurrence of prostate cancer $[9,85,86]$.

Beside the theranostic approach, companion markers include PARP, mesothelin and PD-1/PD-L1-targeting imaging agents.

On the basis of promising preclinical results, selective PARP inhibitors have been developed [94]. Among the imaging agents, PARP imaging with ${ }^{18} \mathrm{~F}$-fluorthanatrace was successful in the breast cancer model [95]. This agent is currently under clinical investigation in several clinical trials on ovarian, prostate, pancreatic and recurrent or metastatic breast cancer (NCT03604315, NCT03334500, NCT03492164, NCT03846167).

A third of breast cancers overexpress mesothelin, a 40-kDa membrane-associated glycoprotein playing a major role during tumor progression. Mesothelin is involved in the epithelium-mesenchymal transition, resistance to apoptosis and tumor invasion [96,97]. It is overexpressed in the most aggressive cancers and its expression is very low in physiological conditions. Hence, several molecules are currently in clinical phases to evaluate the therapeutic performance of its targeting in tumors expressing mesothelin [96]. Among companion markers, some monoclonal antibodies and nanobodies have been evaluated in clinical and in preclinical models of breast cancers [89-91]. Once available in clinical practice, such agents will allow selecting patients eligible to all these therapies.

Finally, molecular imaging of the immune checkpoint receptor PD-1 and its ligand PD-L1 is investigated to monitor immune therapy targeting this axis. Some clinical trials with monoclonal antibodies and nanobodies are in clinical phases for the non-invasive imaging of PD-1/PD-L1 [87]. The chemokine receptor is also frequently overexpressed in invasive breast cancer and the diagnostic performance of CXCR4-directed PET imaging have been successfully assessed in recurrent breast cancer [88]. 
Other targets such as the epidermal growth factor receptor (EGFR) or Mucin-1 represent relevant targets for this theranostic approach [98-100].

\section{Conclusions}

The heterogeneity between the primary tumor and a secondary lesion raises the problem of the management of metastatic breast cancer based on the molecular markers of the primary site. Therefore, the phenotype of each lesion must be determined to personalize the management of each patient. The era of theranostic in nuclear medicine and its considerable contribution to precision is a key methodology of cancer treatment in the next decade.

Author Contributions: Writing-initial manuscript preparation, C.M.; data collection and interpretation, C.M. figures and visualization, C.M. and G.P. Writing-review and editing, C.M. and G.P.; supervision, C.M. and G.P. All authors have read and agreed to the published version of the manuscript.

Funding: This review did not receive any specific funding.

Conflicts of Interest: The authors declare no conflict of interest.

\section{References}

1. Ferlay, J.; Steliarova-Foucher, E.; Lortet-Tieulent, J.; Rosso, S.; Coebergh, J.W.; Comber, H.; Forman, D.; Bray, F. Cancer incidence and mortality patterns in Europe: Estimates for 40 countries in 2012. Eur. J. Cancer 2013, 49, 1374-1403. [CrossRef] [PubMed]

2. Bray, F.; Ferlay, J.; Soerjomataram, I.; Siegel, R.L.; Torre, L.A.; Jemal, A. Global cancer statistics 2018: GLOBOCAN estimates of incidence and mortality worldwide for 36 cancers in 185 countries. CA Cancer J. Clin. 2018, 68, 394-424. [CrossRef] [PubMed]

3. Sorlie, T.; Tibshirani, R.; Parker, J.; Hastie, T.; Marron, J.S.; Nobel, A.; Deng, S.; Johnsen, H.; Pesich, R.; Geisler, S.; et al. Repeated observation of breast tumor subtypes in independent gene expression data sets. Proc. Natl. Acad. Sci. USA 2003, 100, 8418-8423. [PubMed]

4. Perou, C.M.; Sørlie, T.; Eisen, M.B.; van de Rijn, M.; Jeffrey, S.S.; Rees, C.A.; Pollack, J.R.; Ross, D.T.; Johnsen, H.; Akslen, L.A.; et al. Molecular portraits of human breast tumours. Nature 2000, 406, 747-752.

5. Anders, C.K.; Carey, L.A. Biology, metastatic patterns, and treatment of patients with triple-negative breast cancer. Clin. Breast Cancer 2009, 9, S73-S81. [CrossRef]

6. Jemal, A.; Ward, E.M.; Johnson, C.J.; Cronin, K.A.; Ma, J.; Ryerson, B.; Mariotto, A.; Lake, A.J.; Wilson, R.; Sherman, R.L.; et al. Annual Report to the Nation on the Status of Cancer, 1975-2014, Featuring Survival. J. Natl. Cancer Inst. 2017, 109, djx030. [CrossRef]

7. Early Breast Cancer Trialists' Collaborative Group (EBCTCG). Effects of chemotherapy and hormonal therapy for early breast cancer on recurrence and 15-year survival: An overview of the randomised trials. Lancet Lond. Engl. 2005, 365, 1687-1717. [CrossRef]

8. Lindström, L.S.; Karlsson, E.; Wilking, U.M.; Johansson, U.; Hartman, J.; Lidbrink, E.K.; Hatschek, T.; Skoog, L.; Bergh, J. Clinically used breast cancer markers such as estrogen receptor, progesterone receptor, and human epidermal growth factor receptor 2 are unstable throughout tumor progression. J. Clin. Oncol. Off. J. Am. Soc. Clin. Oncol. 2012, 30, 2601-2608. [CrossRef]

9. Yordanova, A.; Eppard, E.; Kürpig, S.; Bundschuch, R.A.; Schonberger, S.; Gonzalez-Carmona, M.; Feldmann, G.; Ahmadzadehfar, H.; Essler, M. Theranostics in nuclear medicine practice. OncoTargets Ther. 2017, 10, 4821-4828.

10. Seyfried, T.N.; Huysentruyt, L.C. On the Origin of Cancer Metastasis. Crit. Rev. Oncog. 2013, 18, 43-73.

11. Jin, X.; Mu, P. Targeting Breast Cancer Metastasis. Breast Cancer Basic Clin. Res. 2015, 9, 23-34. [CrossRef] [PubMed]

12. Hoeferlin, L.A.; Chalfant, C.E.; Park, M.A. Challenges in the Treatment of Triple Negative and HER2-Overexpressing Breast Cancer. J. Surg. Sci. 2013, 1, 3-7. [PubMed]

13. Largillier, R.; Ferrero, J.-M.; Doyen, J.; Barriere, J.; Namer, M.; Mari, V.; Courdi, A.; Hannon-Levi, J.M.; Ettore, F.; Birtwisle-Peyrottes, I.; et al. Prognostic factors in 1,038 women with metastatic breast cancer. Ann. Oncol. Off. J. Eur. Soc. Med. Oncol. 2008, 19, 2012-2019. [CrossRef] [PubMed] 
14. Wu, Q.; Li, J.; Zhu, S.; Wu, J.; Chen, C.; Liu, Q.; Wei, W.; Zhang, Y.; Sun, S. Breast cancer subtypes predict the preferential site of distant metastases: A SEER based study. Oncotarget 2017, 8, 27990-27996. [CrossRef] [PubMed]

15. Tham, Y.-L.; Sexton, K.; Kramer, R.; Hilsenbeck, S.; Elledge, R. Primary breast cancer phenotypes associated with propensity for central nervous system metastases. Cancer 2006, 107, 696-704. [CrossRef] [PubMed]

16. Smid, M.; Wang, Y.; Zhang, Y.; Sieuwerts, A.M.; Klijn, J.G.; Foekens, J.A.; Martens, J.W. Subtypes of breast cancer show preferential site of relapse. Cancer Res. 2008, 68, 3108-3114. [CrossRef] [PubMed]

17. Witzel, I.; Oliveira-Ferrer, L.; Pantel, K.; Müller, V.; Wikman, H. Breast cancer brain metastases: Biology and new clinical perspectives. Breast Cancer Res. 2016, 18, 8. [CrossRef]

18. van Maaren, M.C.; de Munck, L.; Strobbe, L.J.A.; Sonke, G.S.; Westenend, P.J.; Smidt, M.L.; Poortmans, P.M.P.; Siesling, S. Ten-year recurrence rates for breast cancer subtypes in the Netherlands: A large population-based study. Int. J. Cancer 2019, 144, 263-272. [CrossRef]

19. Minicozzi, P.; Bella, F.; Toss, A.; Giacomin, A.; Fusco, M.; Zarcone, M.; Tumino, R.; Falcini, F.; Cesaraccio, R.; Candela, G.; et al. Relative and disease-free survival for breast cancer in relation to subtype: A population-based study. J. Cancer Res. Clin. Oncol. 2013, 139, 1569-1577. [CrossRef]

20. Klein, C.A.; Blankenstein, T.J.F.; Schmidt-Kittler, O.; Petronio, M.; Polzer, B.; Stoecklein, N.H.; Riethmüller, G. Genetic heterogeneity of single disseminated tumour cells in minimal residual cancer. Lancet Lond. Engl. 2002, 360, 683-689. [CrossRef]

21. Schmidt-Kittler, O.; Ragg, T.; Daskalakis, A.; Granzow, M.; Ahr, A.; Blankenstein, T.J.; Kaufmann, M.; Diebold, J.; Arnholdt, H.; Muller, P.; et al. From latent disseminated cells to overt metastasis: Genetic analysis of systemic breast cancer progression. Proc. Natl. Acad. Sci. USA 2003, 100, 7737-7742. [CrossRef] [PubMed]

22. Braun, S.; Pantel, K.; Müller, P.; Janni, W.; Hepp, F.; Kentenich, C.R.; Gastroph, S.; Wischnik, A.; Dimpfl, T.; Kindermann, G.; et al. Cytokeratin-positive cells in the bone marrow and survival of patients with stage I, II, or III breast cancer. N. Engl. J. Med. 2000, 342, 525-533. [CrossRef] [PubMed]

23. Hüsemann, Y.; Geigl, J.B.; Schubert, F.; Musiani, P.; Meyer, M.; Burghart, E.; Forni, G.; Eils, R.; Fehm, T.; Riethmüller, G.; et al. Systemic spread is an early step in breast cancer. Cancer Cell 2008, 13, 58-68.

24. Eyles, J.; Puaux, A.-L.; Wang, X.; Toh, B.; Prakash, C.; Hong, M.; Tan, T.G.; Zheng, L.; Ong, L.C.; Jin, Y.; et al. Tumor cells disseminate early, but immunosurveillance limits metastatic outgrowth, in a mouse model of melanoma. J. Clin. Investig. 2010, 120, 2030-2039. [CrossRef]

25. Rhim, A.D.; Mirek, E.T.; Aiello, N.M.; Maitra, A.; Bailey, J.M.; McAllister, F.; Reichert, M.; Beatty, G.L.; Rustgi, A.K.; Vonderheide, R.H.; et al. EMT and dissemination precede pancreatic tumor formation. Cell 2012, 148, 349-361. [CrossRef]

26. Sänger, N.; Effenberger, K.E.; Riethdorf, S.; Van Haasteren, V.; Gauwerky, J.; Wiegratz, I.; Strebhardt, K.; Kaufmann, M.; Pantel, K. Disseminated tumor cells in the bone marrow of patients with ductal carcinoma in situ. Int. J. Cancer 2011, 129, 2522-2526. [CrossRef]

27. Banys, M.; Gruber, I.; Krawczyk, N.; Becker, S.; Kurth, R.; Wallwiener, D.; Jakubowska, J.; Hoffmann, J.; Rothmund, R.; Staebler, A.; et al. Hematogenous and lymphatic tumor cell dissemination may be detected in patients diagnosed with ductal carcinoma in situ of the breast. Breast Cancer Res. Treat. 2012, 131, 801-808. [CrossRef]

28. Wikman, H.; Vessella, R.; Pantel, K. Cancer micrometastasis and tumour dormancy. Acta. Pathol. Microbiol. Immunol. Scand. 2008, 116, 754-770. [CrossRef]

29. Gomis, R.R.; Gawrzak, S. Tumor cell dormancy. Mol. Oncol. 2017, 11, 62-78. [CrossRef]

30. Almog, N. Molecular mechanisms underlying tumor dormancy. Cancer Lett. 2010, 294, 139-146. [CrossRef]

31. Pantel, K.; Brakenhoff, R.H.; Brandt, B. Detection, clinical relevance and specific biological properties of disseminating tumour cells. Nat. Rev. Cancer 2008, 8, 329-340. [CrossRef] [PubMed]

32. Aguirre-Ghiso, J.A. Models, mechanisms and clinical evidence for cancer dormancy. Nat. Rev. Cancer 2007, 7, 834-846. [CrossRef] [PubMed]

33. Grabinski, N.; Bartkowiak, K.; Grupp, K.; Brandt, B.; Pantel, K.; Jücker, M. Distinct functional roles of Akt isoforms for proliferation, survival, migration and EGF-mediated signalling in lung cancer derived disseminated tumor cells. Cell Signal. 2011, 23, 1952-1960. [CrossRef] [PubMed]

34. Koebel, C.M.; Vermi, W.; Swann, J.B.; Zerafa, N.; Rodig, S.J.; Old, L.J.; Smyth, M.J.; Schreiber, R.D. Adaptive immunity maintains occult cancer in an equilibrium state. Nature 2007, 450, 903-907. [CrossRef] 
35. Pagani, O.; Senkus, E.; Wood, W.; Colleoni, M.; Cufer, T.; Kyriakides, S.; Costa, A.; Winer, E.P.; Cardoso, F. International Guidelines for Management of Metastatic Breast Cancer: Can Metastatic Breast Cancer Be Cured? J. Natl. Cancer Inst. 2010, 102, 456-463. [CrossRef]

36. Gavilá, J.; Lopez-Tarruella, S.; Saura, C.; Munoz, M.; Oliveira, M.; De la Cruz-Merino, L.; Morales, S.; Alvarez, I.; Virizuela, J.A.; Martin, M. SEOM clinical guidelines in metastatic breast cancer 2015. Clin. Transl. Oncol. 2015, 17, 946-955. [CrossRef]

37. Roulot, A.; Héquet, D.; Guinebretière, J.-M.; Vincent-Salomon, A.; Lerebours, F.; Dubot, C.; Rouzier, R. Tumoral heterogeneity of breast cancer. Ann. Biol. Clin. 2016, 74, 653-660. [CrossRef]

38. Santinelli, A.; Pisa, E.; Stramazzotti, D.; Fabris, G. HER-2 status discrepancy between primary breast cancer and metastatic sites. Impact on target therapy. Int. J. Cancer 2007, 122, 999-1004. [CrossRef]

39. Karagöz Özen, D.S.; Ozturk, M.A.; Aydin, Ö.; Turna, Z.H.; Ilvan, S.; Özgüroglu, M. Receptor expression discrepancy between primary and metastatic breast cancer lesions. Oncol. Res. Treat. 2014, 37, 622-626. [CrossRef]

40. Rosen, P.P.; Menendez-Botet, C.J.; Urban, J.A.; Fracchia, A.; Schwartz, M.K. Estrogen receptor protein (ERP) in multiple tumor specimens from individual patients with breast cancer. Cancer 1977, 39, 2194-2200. [CrossRef]

41. Webster, D.J.; Bronn, D.G.; Minton, J.P. Estrogen receptor levels in multiple biopsies from patients with breast cancer. Am. J. Surg. 1978, 136, 337-338. [CrossRef]

42. Holdaway, I.M.; Bowditch, J.V. Variation in receptor status between primary and metastatic breast cancer. Cancer 1983, 52, 479-485. [CrossRef]

43. Foukakis, T.; Åström, G.; Lindström, L.; Hatschek, T.; Bergh, J. When to order a biopsy to characterise a metastatic relapse in breast cancer. Ann. Oncol. Off. J. Eur. Soc. Med. Oncol. 2012, 23, x349-x353. [CrossRef] [PubMed]

44. Guarneri, V.; Giovannelli, S.; Ficarra, G.; Bettelli, S.; Maiorana, A.; Piacentini, F.; Barbieri, E.; Vittoria Dieci, M.; D'Amico, R.; Jovic, G.; et al. Comparison of HER-2 and hormone receptor expression in primary breast cancers and asynchronous paired metastases: Impact on patient management. Oncologist 2008, 13, 838-844. [CrossRef]

45. Koren, S.; Bentires-Alj, M. Breast Tumor Heterogeneity: Source of Fitness, Hurdle for Therapy. Mol. Cell 2015, 60, 537-546. [CrossRef]

46. Billaud, M. L’hétérogénéité intratumorale-Un obstacle darwinien à la médecine personnalisée? Médecine/Sciences 2012, 28, 1116-1119. [CrossRef]

47. Vaupel, P. Hypoxia and aggressive tumor phenotype: Implications for therapy and prognosis. Oncologist 2008, 13, 21-26. [CrossRef]

48. Dagogo-Jack, I.; Shaw, A.T. Tumour heterogeneity and resistance to cancer therapies. Nat. Rev. Clin. Oncol. 2018, 15, 81-94. [CrossRef]

49. Jin, G.; Han, Y.; Liu, C.; Chen, L.; Ding, B.; Xuan, S.; Liu, X.; Ma, G.; Gao, J.; Tian, X. Evaluation of biomarker changes after administration of various neoadjuvant chemotherapies in breast cancer. Int. J. Clin. Exp. Pathol. 2015, 8, 914-921.

50. Yang, Y.-F.; Liao, Y.-Y.; Li, L.-Q.; Xie, S.-R.; Xie, Y.-F.; Peng, N.-F. Changes in ER, PR and HER2 receptors status after neoadjuvant chemotherapy in breast cancer. Pathol. Res. Pract. 2013, 209, 797-802. [CrossRef]

51. Yoshida, A.; Hayashi, N.; Suzuki, K.; Takimoto, M.; Nakamura, S.; Yamauchi, H. Change in HER2 status after neoadjuvant chemotherapy and the prognostic impact in patients with primary breast cancer. J. Surg. Oncol. 2017, 116, 1021-1028. [CrossRef] [PubMed]

52. Botteri, E.; Disalvatore, D.; Curigliano, G.; Brollo, J.; Bagnardi, V.; Viale, G.; Orsi, F.; Goldhirsch, A.; Rotmensz, N. Biopsy of liver metastasis for women with breast cancer: Impact on survival. Breast Edinb. Scotl. 2012, 21, 284-288. [CrossRef] [PubMed]

53. Van Heertum, R.L.; Scarimbolo, R.; Ford, R.; Berdougo, E.; O’Neal, M. Companion diagnostics and molecular imaging-enhanced approaches for oncology clinical trials. Drug Des. Devel. Ther. 2015, 9, 5215-5223. [CrossRef] [PubMed]

54. Sörensen, J.; Velikyan, I.; Sandberg, D.; Wennborg, A.; Feldwisch, J.; Tolmachev, V.; Orlova, A.; Sandström, M.; Lubberink, M.; Olofsson, H.; et al. Measuring HER2-Receptor Expression In Metastatic Breast Cancer Using [68 Ga] ABY-025 Affibody PET/CT. Theranostics 2016, 6, 262-271. 
55. Ulaner, G.A.; Hyman, D.M.; Ross, D.S.; Corben, A.; Chandarlapaty, S.; Goldfarb, S.; McArthur, H.; Erinjeri, J.P.; Solomon, S.B.; Kolb, H.; et al. Detection of HER2-Positive Metastases in Patients with HER2-Negative Primary Breast Cancer Using 89Zr-Trastuzumab PET/CT. J. Nucl. Med. Off. Publ. Soc. Nucl. Med. 2016, 57, 1523-1528. [CrossRef]

56. Mariotto, A.B.; Etzioni, R.; Hurlbert, M.; Penberthy, L.; Mayer, M. Estimation of the Number of Women Living with Metastatic Breast Cancer in the United States. Cancer Epidemiol. Prev. Biomark. 2017, 26, 809-815. [CrossRef]

57. Daly, M.J. Death by protein damage in irradiated cells. DNA Repair. 2012, 11, 12-21. [CrossRef]

58. Baskar, R.; Dai, J.; Wenlong, N.; Yeo, R.; Yeoh, K.-W. Biological response of cancer cells to radiation treatment. Front. Mol. Biosci. 2014, 1, 24. [CrossRef]

59. Prise, K.M.; Schettino, G.; Folkard, M.; Held, K.D. New insights on cell death from radiation exposure. Lancet Oncol. 2005, 6, 520-528. [CrossRef]

60. Maier, P.; Hartmann, L.; Wenz, F.; Herskind, C. Cellular Pathways in Response to Ionizing Radiation and Their Targetability for Tumor Radiosensitization. Int. J. Mol. Sci. 2016, 17, 102. [CrossRef]

61. Blower, P.J. A nuclear chocolate box: The periodic table of nuclear medicine. Dalton. Trans. Camb. Engl. 2015, 44, 4819-4844. [CrossRef] [PubMed]

62. Brady, D.; O'Sullivan, J.M.; Prise, K.M. What is the Role of the Bystander Response in Radionuclide Therapies? Front. Oncol. 2013, 3, 215. [CrossRef] [PubMed]

63. Sathekge, M.; Bruchertseifer, F.; Knoesen, O.; Reyneke, F.; Lawal, I.; Lengana, T.; Davis, C.; Mahapane, J.; Corbett, C.; Vorster, M.; et al. 225Ac-PSMA-617 in chemotherapy-naive patients with advanced prostate cancer: A pilot study. Eur. J. Nucl. Med. Mol. Imaging 2019, 46, 129-138. [CrossRef] [PubMed]

64. Kratochwil, C.; Bruchertseifer, F.; Rathke, H.; Bronzel, M.; Apostolidis, C.; Weichert, W.; Haberkorn, U.; Giesel, F.L.; Morgenstern, A. Targeted $\alpha$-Therapy of Metastatic Castration-Resistant Prostate Cancer with 225Ac-PSMA-617: Swimmer-Plot Analysis Suggests Efficacy Regarding Duration of Tumor Control. J. Nucl. Med. Off. Publ. Soc. Nucl. Med. 2018, 59, 795-802. [CrossRef]

65. Kratochwil, C.; Bruchertseifer, F.; Rathke, H.; Bronzel, M.; Apostolidis, C.; Weichert, W.; Haberkorn, U.; Giesel, F.L.; Morgenstern, A. Targeted $\alpha$-Therapy of Metastatic Castration-Resistant Prostate Cancer with 225Ac-PSMA-617: Dosimetry Estimate and Empiric Dose Finding. J. Nucl. Med. Off. Publ. Soc. Nucl. Med. 2017, 58, 1624-1631.

66. Liu, F.; Zhu, H.; Yu, J.; Han, X.; Xie, Q.; Liu, T.; Xia, C.; Li, N.; Yang, Z. 68Ga/177Lu-labeled DOTA-TATE shows similar imaging and biodistribution in neuroendocrine tumor model. Tumour. Biol. J. Int. Soc. Oncodev. Biol. Med. 2017, 39, 1010428317705519. [CrossRef]

67. Maffey-Steffan, J.; Scarpa, L.; Svirydenka, A.; Fink, K.; Bektic, J.; Gruber, L.; Decristoforo, C.; Uprimny, C.; Lukas, P.; Horninger, W.; et al. The $68 \mathrm{Ga} / 177 \mathrm{Lu}$-theragnostic concept in PSMA-targeting of metastatic castration-resistant prostate cancer: Impact of post-therapeutic whole-body scintigraphy in the follow-up. Eur. J. Nucl. Med. Mol. Imaging 2020, 47, 695-712. [CrossRef]

68. Dalm, S.U.; Bakker, I.L.; de Blois, E.; Doeswijk, G.N.; Konijnenberg, M.W.; Orlandi, F.; Barbato, D.; Tedesco, M.; Maina, T.; Nock, B.A.; et al. 68Ga/177Lu-NeoBOMB1, a Novel Radiolabeled GRPR Antagonist for Theranostic Use in Oncology. J. Nucl. Med. Off. Publ. Soc. Nucl. Med. 2017, 58, 293-299.

69. Strosberg, J.; El-Haddad, G.; Wolin, E.; Hendifar, A.; Yao, J.; Chasen, B.; Mittra, E.; Kunz, P.L.; Kulke, M.H.; Jacene, H.; et al. Phase 3 Trial of 177Lu-Dotatate for Midgut Neuroendocrine Tumors. N. Engl. J. Med. 2017, 376, 125-135. [CrossRef]

70. Kabasakal, L.; Toklu, T.; Yeyin, N.; Demirci, E.; Abuqbeitah, M.; Ocak, M.; Aygün, A.; Karayel, E.; Pehlivanoğlu, H.; Alan Selçuk, N. Lu-177-PSMA-617 Prostate-Specific Membrane Antigen Inhibitor Therapy in Patients with Castration-Resistant Prostate Cancer: Stability, Bio-distribution and Dosimetry. Mol. Imaging Radionucl. Ther. 2017, 26, 62-68. [CrossRef]

71. Han, S.; Woo, S.; Kim, Y.J.; Suh, C.H. Impact of 68Ga-PSMA PET on the Management of Patients with Prostate Cancer: A Systematic Review and Meta-analysis. Eur. Urol. 2018, 74, 179-190. [CrossRef] [PubMed]

72. Marcu, L.; Bezak, E.; Allen, B.J. Global comparison of targeted alpha vs targeted beta therapy for cancer: In vitro, in vivo and clinical trials. Crit. Rev. Oncol. Hematol. 2018, 123, 7-20. [CrossRef] [PubMed]

73. Tamura, K.; Kurihara, H.; Yonemori, K.; Tsuda, H.; Suzuki, J.; Kono, Y.; Honda, N.; Kodaira, M.; Yamamoto, H.; Yunokawa, M.; et al. 64Cu-DOTA-trastuzumab PET imaging in patients with HER2-positive breast cancer. J. Nucl. Med. Off. Publ. Soc. Nucl. Med. 2013, 54, 1869-1875. [CrossRef] [PubMed] 
74. Dijkers, E.C.F.; Kosterink, J.G.W.; Rademaker, A.P.; Perk, L.R.; van Dongen, G.A.; Bart, J.; de Jong, J.R.; de Vries, E.G.; Lub-de Hooge, M.N. Development and characterization of clinical-grade 89Zr-trastuzumab for HER2/neu immunoPET imaging. J. Nucl. Med. Off. Publ. Soc. Nucl. Med. 2009, 50, 974-981. [CrossRef] [PubMed]

75. Vaneycken, I.; Devoogdt, N.; Van Gassen, N.; Vincke, C.; Xavier, C.; Wernery, U.; Muyldermans, S.; Lahoutte, T.; Caveliers, V. Preclinical screening of anti-HER2 nanobodies for molecular imaging of breast cancer. FASEB J. Off. Publ. Fed. Am. Soc. Exp. Biol. 2011, 25, 2433-2446. [CrossRef] [PubMed]

76. Xavier, C.; Vaneycken, I.; D’huyvetter, M.; Heemskerk, J.; Keyaerts, M.; Vincke, C.; Devoogdt, N.; Muyldermans, S.; Lahoutte, T.; Caveliers, V. Synthesis, preclinical validation, dosimetry, and toxicity of 68Ga-NOTA-anti-HER2 Nanobodies for iPET imaging of HER2 receptor expression in cancer. J. Nucl. Med. Off. Publ. Soc. Nucl. Med. 2013, 54, 776-784. [CrossRef]

77. D'Huyvetter, M.; Vincke, C.; Xavier, C.; Aerts, A.; Impens, N.; Baatout, S.; De Raeve, H.; Muyldermans, S.; Caveliers, V.; Devoogdt, N.; et al. Targeted radionuclide therapy with A 177Lu-labeled anti-HER2 nanobody. Theranostics 2014, 4, 708-720. [CrossRef]

78. Keyaerts, M.; Xavier, C.; Heemskerk, J.; Devoogdt, N.; Everaert, H.; Ackaert, C.; Vanhoeij, M.; Duhoux, F.P.; Gevaert, T.; Simon, P.; et al. Phase I Study of 68Ga-HER2-Nanobody for PET/CT Assessment of HER2 Expression in Breast Carcinoma. J. Nucl. Med. Off. Publ. Soc. Nucl. Med. 2016, 57, 27-33. [CrossRef]

79. McGuire, A.H.; Dehdashti, F.; Siegel, B.A.; Lyss, A.P.; Brodack, J.W.; Mathias, C.J.; Mintun, M.A.; Katzenellenbogen, J.A.; Welch, M.J. Positron Tomographic Assessment of 16a-[18F] Fluoro-17/3-Estradiol Uptake in Metastatic Breast Carcinoma. J. Nucl. Med. 1991, 32, 1526-1531.

80. Evangelista, L.; Guarneri, V.; Conte, P.F. 18F-Fluoroestradiol Positron Emission Tomography in Breast Cancer Patients: Systematic Review of the Literature \& Meta-Analysis. Curr. Radiopharm. 2016, 9, $244-257$.

81. Koleva-Kolarova, R.G.; Greuter, M.J.W.; van Kruchten, M.; Vermeulen, K.M.; Feenstra, T.; Buskens, E.; Glaudemans, A.W.J.M.; de Vries, E.F.J.; de Vries, E.G.E.; Hospers, G.A.P.; et al. The value of PET/CT with FES or FDG tracers in metastatic breast cancer: A computer simulation study in ER-positive patients. Br. J. Cancer 2015, 112, 1617-1625. [CrossRef] [PubMed]

82. Mortimer, J.E.; Dehdashti, F.; Siegel, B.A.; Trinkaus, K.; Katzenellenbogen, J.A.; Welch, M.J. Metabolic Flare: Indicator of Hormone Responsiveness in Advanced Breast Cancer. J. Clin. Oncol. 2001, 19, 2797-2803. [CrossRef] [PubMed]

83. Chae, S.Y.; Ahn, S.H.; Kim, S.-B.; Han, S.; Lee, S.H.; Oh, S.J.; Lee, S.J.; Kim, H.J.; Ko, B.S.; Lee, J.W.; et al. Diagnostic accuracy and safety of $16 \alpha$-[18F]fluoro-17 $\beta$-oestradiol PET-CT for the assessment of oestrogen receptor status in recurrent or metastatic lesions in patients with breast cancer: A prospective cohort study. Lancet Oncol. 2019, 20, 546-555. [CrossRef]

84. Edmonds, C.E.; Makvandi, M.; Lieberman, B.P.; Xu, K.; Zeng, C.; Li, S.; Hou, C.; Lee, H.; Greenberg, R.A.; Mankoff, D.A.; et al. [18F]FluorThanatrace uptake as a marker of PARP1 expression and activity in breast cancer. Am. J. Nucl. Med. Mol. Imaging 2016, 6, 94-101.

85. Rahbar, K.; Schmidt, M.; Heinzel, A.; Eppard, E.; Bode, A.; Yordanova, A.; Claesener, M.; Ahmadzadehfar, H. Response and Tolerability of a Single Dose of 177Lu-PSMA-617 in Patients with Metastatic Castration-Resistant Prostate Cancer: A Multicenter Retrospective Analysis. J. Nucl. Med. Off. Publ. Soc. Nucl. Med. 2016, 57, 1334-1338. [CrossRef]

86. Hofman, M.S.; Violet, J.; Hicks, R.J.; Ferdinandus, J.; Thang, S.P.; Akhurst, T.; Iravani, A.; Kong, G.; Ravi Kumar, A.; Murphy, D.G.; et al. [177Lu]-PSMA-617 radionuclide treatment in patients with metastatic castration-resistant prostate cancer (LuPSMA trial): A single-centre, single-arm, phase 2 study. Lancet Oncol. 2018, 19, 825-833. [CrossRef]

87. Broos, K.; Lecocq, Q.; Raes, G.; Devoogdt, N.; Keyaerts, M.; Breckpot, K. Noninvasive imaging of the PD-1:PD-L1 immune checkpoint: Embracing nuclear medicine for the benefit of personalized immunotherapy. Theranostics 2018, 8, 3559-3570. [CrossRef]

88. Vag, T.; Steiger, K.; Rossmann, A.; Keller, U.; Noske, A.; Herhaus, P.; Ettl, J.; Niemeyer, M.; Wester, H.-J.; Schwaiger, M. PET imaging of chemokine receptor CXCR4 in patients with primary and recurrent breast carcinoma. EJNMMI Res. 2018, 8, 90. [CrossRef]

89. Kobayashi, K.; Sasaki, T.; Takenaka, F.; Yakushiji, H.; Fujii, Y.; Kishi, Y.; Kita, S.; Shen, L.; Kumon, H.; Matsuura, E. A novel PET imaging using 64Cu-labeled monoclonal antibody against mesothelin commonly expressed on cancer cells. J. Immunol. Res. 2015, 2015, 268172. [CrossRef] 
90. ter Weele, E.J.; Terwisscha van Scheltinga, A.G.T.; Kosterink, J.G.W.; Pot, L.; Vedelaar, S.R.; Lamberts, L.E.; Williams, S.P.; Lub-de Hooge, M.N.; de Vries, E.G. Imaging the distribution of an antibody-drug conjugate constituent targeting mesothelin with $89 \mathrm{Zr}$ and IRDye $800 \mathrm{CW}$ in mice bearing human pancreatic tumor xenografts. Oncotarget 2015, 6, 42081-42090. [CrossRef]

91. Montemagno, C.; Bacot, S.; Ahmadi, M.; Kerfelec, B.; Baty, D.; Debiossat, M.; Soubies, A.; Perret, P.; Riou, L.; Fagret, D.; et al. Preclinical Evaluation of Mesothelin-Specific Ligands for SPECT Imaging of Triple-Negative Breast Cancer. J. Nucl. Med. Off. Publ. Soc. Nucl. Med. 2018, 59, 1056-1062. [CrossRef] [PubMed]

92. Morgat, C.; MacGrogan, G.; Brouste, V.; Vélasco, V.; Sévenet, N.; Bonnefoi, H.; Fernandez, P.; Debled, M.; Hindié, E. Expression of Gastrin-Releasing Peptide Receptor in Breast Cancer and Its Association with Pathologic, Biologic, and Clinical Parameters: A Study of 1,432 Primary Tumors. J. Nucl. Med. 2017, 58, 1401-1407. [CrossRef] [PubMed]

93. Reubi, J.C.; Wenger, S.; Schmuckli-Maurer, J.; Schaer, J.-C.; Gugger, M. Bombesin receptor subtypes in human cancers: Detection with the universal radioligand (125) I-[D-TYR(6), beta-ALA(11), PHE(13), NLE(14)] bombesin(6-14). Clin. Cancer Res. Off. J. Am. Assoc. Cancer Res. 2002, 8, 1139-1146.

94. Jiang, X.; Li, W.; Li, X.; Bai, H.; Zhang, Z. Current status and future prospects of PARP inhibitor clinical trials in ovarian cancer. Cancer Manag. Res. 2019, 11, 4371-4390. [CrossRef]

95. Zhou, D.; Chu, W.; Xu, J.; Jones, L.A.; Peng, X.; Li, S.; Chen, D.L.; Mach, R.H. Synthesis, [18F] radiolabeling, and evaluation of poly (ADP-ribose) polymerase-1 (PARP-1) inhibitors for in vivo imaging of PARP-1 using positron emission tomography. Bioorg. Med. Chem. 2014, 22, 1700-1707. [CrossRef]

96. Hassan, R.; Thomas, A.; Alewine, C.; Le, D.T.; Jaffee, E.M.; Pastan, I. Mesothelin Immunotherapy for Cancer: Ready for Prime Time? J. Clin. Oncol. 2016, 34, 4171-4179. [CrossRef]

97. Pastan, I.; Hassan, R. Discovery of mesothelin and exploiting it as a target for immunotherapy. Cancer Res. 2014, 74, 2907-2912. [CrossRef]

98. Singh, D.; Attri, B.K.; Gill, R.K.; Bariwal, J. Review on EGFR Inhibitors: Critical Updates. Mini Rev. Med. Chem. 2016, 16, 1134-1166. [CrossRef]

99. Chen, W.; Shen, B.; Sun, X. Analysis of Progress and Challenges of EGFR-Targeted Molecular Imaging in Cancer with a Focus on Affibody Molecules. Mol. Imaging 2019, 18. [CrossRef]

100. Santos do Carmo, F.; Ricci-Junior, E.; Cerqueira-Coutinho, C.; Albernaz, M.; Bernardes, E.S.; Missailidis, S.; Santos-Oliveira, R. Anti-MUC1 nano-aptamers for triple-negative breast cancer imaging by single-photon emission computed tomography in inducted animals: Initial considerations. Int. J. Nanomed. 2016, 12, 53-60. [CrossRef]

(C) 2020 by the authors. Licensee MDPI, Basel, Switzerland. This article is an open access article distributed under the terms and conditions of the Creative Commons Attribution (CC BY) license (http://creativecommons.org/licenses/by/4.0/). 